\title{
Corporate Social Responsibility in Connection with Business Closures and Downsizing: A Literature Review
}

\author{
Roland Ahlstrand \\ Malmö University \\ Alexis Rydell \\ Dalarna University \\ E-Mail: ary@du.se
}

E-Mail: roland.ahlstrand@mah.se

\begin{abstract}
The aim of this paper was to review the research on corporate social responsibility (CSR) in connection with business closures and downsizing to identify gaps in our knowledge. The study consisted of a systematic review of 24 refereed articles. The review identified four themes in the literature on CSR in connection with business closure and downsizing, namely CSR, transition programs and the local community; CSR and business strategy; CSR, power and reputation; and lastly, other articles on CSR in connection with business closures and downsizing. The review revealed a lack of understanding of the reasons, outcomes and methodology of CSR development in connection with business closures and downsizing.
\end{abstract}

Keywords: Corporate Social Responsibility, Business Closures, Downsizing, Literature Review

\section{INTRODUCTION AND BACKGROUND}

The interest in Corporate Social Responsibility has become increasingly widespread and have been adapted to common practice among business people, politicians, trade union representatives, consumers, non-governmental organizations and researchers (Habish et al., 2005). Along with this business trend, several textbooks in the area of CSR have been published in the last decade, elaborating on different types of concepts, theories, contexts, perspectives, relationships, actors, drivers and critique as well as on managing and implementing CSR (Burchell, 2008; Crane \& Matten, 2007a, 2007b, 2007c; Crane et.al., 2008; Crowther \& Rayman-Bacchus, 2004; 
Visser et al., 2008;). Literature reviews have likewise been conducted, focusing largely on measuring the effect of CSR on financial performance; the operationalisation of CSR; differences between CSR and similar concepts; measurement of CSR; the way in which CSR can create value for stakeholders and specific disciplines, such as marketing, organisational behaviour, human resource management, industrial and organisational psychology, and operations (Aguinis \& Glavas, 2012). Furthermore, research has focused on issues of ethics and support to addicts, unemployed, kindergartens and schools, as well as on problems of working conditions and environmental issues in developing countries (Akyildiz, 2006; Carroll, 1999, 1991; Dobbers \& Halme, 2009; Ite, 2004; Jamali, Lund-Thomsen, \& Khara, 2017; Schwartz \& Carroll, 2003). Additional research has questioned the environmental issues in developed countries, codes of conduct, consumption behaviour, accounting, employee relations and human rights (Aguinis \& Glavas, 2012; Crane \& Matten, 2007b; Dobbers, 2010). In addition, the CSR literature has given attention to both small and medium sized enterprises (e.g., Jamali, Lund-Thomsen \& Jeppsen, 2017; Martinez-Conesa, Soto-Acosta \& Palacios-Manzano, 2017; Stoian \& Gilman, 2017) as well as larger multinational corporations (e.g., Droppert \& Bennett, 2015; Filatotchev \& Stahl, 2015; Marano \& Kostova, 2016).

Although, many definitions and ways of understanding CSR have been developed (Dahlsrud, 2006; Moir, 2001), research on CSR has focused mainly on definitions encompassing the economic, legal, ethical, and discretionary expectation that society has of organizations at a certain point of time (Carroll, 1979). Briefly, CSR often means that companies engage in and decide on "actions that appear to further some social good, beyond the interest of the firm and that which is required by law" (McWilliams \& Siegel, 2001: 117). Accordingly, and along with the fact that laws, cultures and norms differ across countries, CSR may be practiced differently, depending on the institutional settings and structures in which the companies operate (cf. Avi-Yonah, 2005; Brejning, 2012; Matten \& Moon, 2008; Williams \& Aguilera, 2008).

Despite comprehensive research, additional areas should be investigated, for example, CSR in connection with business closures and downsizing. For instance, how should CSR be dealt with in these situations? This kind of knowledge could be of great importance for management practices, companies, employees and local communities. Redundant employees, in the best-case scenario, will transition smoothly to new employment and avoid facing unemployment and its negative consequences. Research has indicated that displaced workers may face worsened labour market positions and earning losses (Armstrong et al., 2008; Eliason \& Storrie, 2006), as well as negative 
social or health concerns (Browning \& Heinesen, 2012; Eliason \& Storrie, 2009; Hironimus-Wendt, 2008). Indeed, consequences depend on several issues, for example, the local labour market and its vertical and horizontal division of labour (Gonäs, 1979, 1989; Gonäs \& Westin, 1993), labour market policy measures, business cycle, and individual inclination to move, commute and educate oneself (Angelöw, 1988). The outcome could also depend on the size of affected companies and the existence and effectiveness of different types of support structures, such as collective transition agreements and national laws on company responsibility in the case of closures and downsizings. Nevertheless, CSR can make a difference for the affected stakeholders.

The aim of this paper was to review research on corporate social responsibility in relation to business closures and downsizing in order to identify the current body of knowledge. The review can provide a basis for further research. The following research questions are posed:

RQ1. What are the aims of the studies?

RQ2. What are the findings?

RQ3. What is lacking in current understanding?

\section{LITERATURE REVIEW}

The principles of a systematic review, highlighted by Jesson et al. (2011), guided the review process. These principles include mapping the field through a scoping review, comprehensive search, quality assessment, data extraction, synthesis, and write-up. This approach seems suitable, and it has frequently been used in other literature reviews (e.g., Edvardsson \& Durst, 2014; Durst \& Edvardsson, 2012).

The review process began by searching for relevant studies using several keywords, such as plant closures, plant closing, closing, closedowns, closing down, closure, socially responsible, social responsibility, shutdown, downsizing, and technical terms, such as liquidate and liquidation, as well as the more generic terms, such as dissolve, break up, disband, disbandment, terminate and termination. Additionally, we used quotation marks and the truncation character "**", for instance, clos*, down*, and shut*. The relevant articles had to meet the inclusion criteria in that they had to be peer-reviewed; written in English; available on ProQuest, Web of Science, and Jstor databases as well as the library search engine Summon. Other types of literature, such as working-papers and articles published in languages other than English were excluded from the study. The decision to include only English language peer-reviewed literature was based primarily on the fact that English is the international language used by the researchers worldwide to communicate with each other and to present their research. An approach that has been used in other literature review articles (cf. Edvardsson \& Durst, 2014; Datta et al., 2010). 
Thereafter, an Excel data sheet containing important aspects was created based on the structural model of Edvardsson and Durst (2014) and included name(s) of author(s), year of publication, research aim/objectives, theoretical perspectives/framework, method, main findings and name of the journal, including volume and number of publication.

The ProQuest, Web of Science, Jstor and Summon databases were searched using different combinations of the outlined keywords in the title, abstract, and keywords. For instance, the combination of the keywords social responsibility in the title and closure, closing, and shutdown in the abstract or among the keywords resulted in 12 hits while the combination of social responsibility in the title and downsizing in the abstract resulted in 11 hits in ProQuest. In total, the searches resulted in 153 hits. However, since the searches did not identify many articles published in high-ranked journals with a special interest of corporate social responsibility, the following journals were also searched specifically and separately: Social Responsibility Journal, Corporate Governance: An International Review, Business and Society and Business and Society Review. This resulted in 12 more hits. The searches in the databases were carried out during 2015 and 2016.

The abstracts of the 165 articles were then read. Articles with abstracts that were relevant to this study were selected for further evaluation. Consequently, some articles that were irrelevant to this study or were duplications were excluded while 43 articles that met the aims of the study were retained. After thoroughly reading the articles, articles that did not meet our criteria were excluded. For instance, articles that had CSR as only one parameter among many others or articles that focused on 'survivors' (i.e., remaining employees in the organization) rather than 'victims' (i.e., laid-off employees) of downsizing processes were excluded from the study. In conclusion, 24 articles were included.

In the next stage, the findings were analyzed by intense discussions on the data extraction and synthesis, resulting in four themes representing the main body of the present knowledge of corporate social responsibility in connection with business closures and downsizing. Finally, in accordance with the process of analysis, the findings were recorded.

\section{PRESENTATION OF FINDINGS}

Before continuing to the presentation of the results and content of themes identified in the 24 articles, some remarks should be made concerning year of publication, research methods, countries involved, and journals that published articles on CSR in connection with business closures and downsizing. The oldest study was 
published in 1984 while the most recent publications were from 2014 (Table 1). In between, there were periods when the research interest in CSR in relation to the subject in question seemed to have been quite low.

Table 1 Number of Articles per Year, 1984-2014

\begin{tabular}{|c|c|c|c|c|c|c|c|c|c|c|c|c|c|c|c|c|}
\hline YEAR & $\stackrel{+}{\infty}$ & $\begin{array}{l}\infty \\
\infty \\
\stackrel{\infty}{=}\end{array}$ & ळ & ڤ̆ & $\stackrel{\infty}{2}$ & ळे & \& & ষ্ণ & ஜ & $\stackrel{\infty}{8}$ & $\stackrel{\circ}{\circ}$ & $\vec{\sim}$ & $\stackrel{\sim}{\stackrel{2}{*}}$ & $\stackrel{n}{\stackrel{n}{*}}$ & 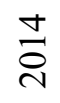 & 岕 \\
\hline $\begin{array}{c}\text { NO. OF } \\
\text { ARTICLES }\end{array}$ & 1 & 1 & 1 & 1 & 2 & 4 & 1 & 1 & 1 & 1 & 1 & 4 & 2 & 1 & 2 & 24 \\
\hline
\end{tabular}

The most common methods used in these articles were case studies (14 articles) and qualitative methods (16 articles). Six studies utilized quantitative methods and two studies used conceptual methods. Some studies also used mixed methods and secondary data. Furthermore, much of the research has been carried out in the US (10 articles) and Sweden (9 articles). Research has also been carried out in Australia (2), Germany (1), Namibia (1), and the UK (1).

Finally, the 24 articles were published across 20 journals. The most common journals were in the area of business ethics (8); management, HRM and organization studies (6); psychology (3); industrial relations and socio-economics (5); environmental and sustainability (1), and public affairs (1).

\section{THE BODY OF KNOWLEDGE}

The review process yielded four themes: CSR, transition programs and the local community; CSR and strategy; CSR, power and reputation; and other articles on CSR in connection with business closures and downsizing.

\section{CSR, Transitions Programs, and The Local Community}

Twelve articles addressed the theme of CSR, transitions programs and the local community (Table 2), assessing how companies act socially responsible by helping employees cope with job loss as well as improve their skills and transition to new employment on the labor market and helping the local community to come to terms with the new situation. The idea of providing assistance to employees is understood as being based on the perception that companies have a moral obligation to ease the pain of the affected workers (Rydell \& Wigblad, 2012). Some of the identified studies used a psychological perspective and focused on social responsibility in connection with employees' reactions (Ramsey, 2014; Tang \& Crofford, 1999). Ramsey (2014), for instance, argued that the management should consider social responsibility by helping 
employees cope with job loss. This could be done by providing employees with emotional support, such as counseling and coaching, in the job search process.

Another important aspect that helps employees cope with closure as well as transition to new employment concerns the duration of the transition period (Millspaugh, 1990; Rydell \& Wigblad, 2012). Longer transition periods give employees better opportunities not only to overcome the initial shock that the announcement may create, but also to undertake efforts to improve their skills and employability during the restructuring processes. Based on several CSR cases, Rydell and Wigblad (2012) argued that longer transition periods would ease the development of "outreach HRM", which includes, for instance, education, business startup education, re-training for new employment, job search assistance, transfer to other plants in the group, as well as cooperation with local community educational actors. Regardless of the duration of transition periods, research in the US found that offshoring outsourcing companies that were downsizing preferred to support public and private education instead of providing training programs for laid-off employees (Tesfom \& Birch, 2008).

Local communities that are left behind after corporate restructurings may, in some instances, face difficulties, since the unemployment rate and social costs can increase while tax revenues decrease. Research has focused mainly on restructuring of mining industries (Browne, Stehlik \& Buckle, 2011; Littlewood, 2014) and larger manufacturing companies (McMahon, 1999; Rydell \& Wigblad, 2011; Wigblad, 1995) often located in rural areas. In these cases, companies can play important roles in different ways, by helping and supporting the local community that is affected by corporate restructuring in order to revival local economy during and after the restructuring process (Ahlstrand, 2010; Carroll 1984; McMahon 1999; Wigblad, 1995).

Carroll (1984) highlighted several areas of socially responsible management actions to handle public affairs during closedown processes, including, among other things, community impact analysis, outplacement benefits, gradual phase out, and attracting replacement industry. Concerning the latter, to help the local community in the process of attracting replacement industries, the strategy has the "overwhelming advantage of rapidly replacing large numbers of lost jobs" (Carroll, 1984: 136). In this vein, Rydell and Wigblad (2011) reported on a closedown case where the management "near-sourced" some parts of the production by letting sub-contractors take over some production processes in the abandoned facilities and hire almost one-third of the displaced work-force. Research has also reported unusual proactive approaches. For instance, Wigblad (1995) described how a Swedish company, in close collaboration with the representatives from the unions, the state, and the local community, actively 
worked together to locate new industry for the local community during a noteworthy long closedown period of almost four years. The collaboration was based on a high level of trust between the involved parties (Wigblad, 1995).

In other, rarer cases, companies have contributed economically to the community by, for instance, donating manufacturing and office space and offering monetary capital to reinvigorate the local community (McMahon, 1999). However, the effect of the restructuring of the local community is sensitive to the business cycle, where it is favorable to do restructurings during an upturn in the economy, since normally, more alternative jobs are available for the workers in the local labor market (Rydell \& Wigblad 2011; Wigblad, 1995).

Table 2 Articles on CSR, Transition Programs and The Local Community

\begin{tabular}{|c|c|c|c|c|c|}
\hline $\begin{array}{c}\text { Author(s) } \\
\text { (year) }\end{array}$ & $\begin{array}{l}\text { Research aims/ } \\
\text { objectives }\end{array}$ & $\begin{array}{c}\text { Theoretical perspective/ } \\
\text { framework }\end{array}$ & $\begin{array}{c}\text { Method } \\
\text { (empirical/theoretical) }\end{array}$ & Main findings & Journal \\
\hline $\begin{array}{l}\text { Tesfom } \\
\text { and Birch } \\
(2008)\end{array}$ & $\begin{array}{l}\text { To determine how } \\
\text { offshore } \\
\text { outsourcing firms } \\
\text { in the USA are } \\
\text { involved in } \\
\text { providing } \\
\text { assistance to } \\
\text { training and } \\
\text { education to the } \\
\text { downsized. The } \\
\text { purpose is also to } \\
\text { conduct } \\
\text { inter-industry } \\
\text { comparisons } \\
\text { among offshore } \\
\text { outsourcing firms } \\
\text { to determine if } \\
\text { there are } \\
\text { differences in their } \\
\text { degree of } \\
\text { involvement in } \\
\text { assisting training } \\
\text { and education to } \\
\text { the downsized. }\end{array}$ & $\begin{array}{l}\text { Literature related to the } \\
\text { offshore outsourcing, and } \\
\text { CSR. }\end{array}$ & $\begin{array}{l}\text { Survey of } 51 \text { firms in } \\
\text { the USA that are listed } \\
\text { as major offshore } \\
\text { outsourcers, and } \\
\text { exporters of American } \\
\text { jobs in CNN's Lou } \\
\text { Dobbs Exporting } \\
\text { America website. }\end{array}$ & $\begin{array}{l}\text { The main findings } \\
\text { show that offshore } \\
\text { outsourcing firms } \\
\text { were least involved } \\
\text { in providing or } \\
\text { supporting training } \\
\text { programs to the } \\
\text { downsized or } \\
\text { unemployed. } \\
\text { However, the results } \\
\text { show that offshore } \\
\text { outsourcing firms } \\
\text { were highly involved } \\
\text { in providing } \\
\text { assistance to charities } \\
\text { and supporting both } \\
\text { public and private } \\
\text { and education. }\end{array}$ & $\begin{array}{l}\text { Social } \\
\text { Responsibility } \\
\text { Journal, 4(4): } \\
\text { 428-438. }\end{array}$ \\
\hline $\begin{array}{l}\text { Millspaugh } \\
\text { (1990) }\end{array}$ & $\begin{array}{l}\text { This article } \\
\text { examines evidence } \\
\text { of what is said to } \\
\text { be a stubborn } \\
\text { ethical impulse in } \\
\text { American public } \\
\text { policy pertaining } \\
\text { to business } \\
\text { closures. }\end{array}$ & $\begin{array}{l}\text { Literature related to } \\
\text { socially responsible plant } \\
\text { closings and relevant } \\
\text { legalization in the US. }\end{array}$ & $\begin{array}{l}\text { Secondary data analysis } \\
\text { of literature and } \\
\text { legalization. }\end{array}$ & $\begin{array}{l}\text { The findings suggest } \\
\text { that the requirements } \\
\text { of advanced notice } \\
\text { and worker severance } \\
\text { pay have begun to } \\
\text { root in American } \\
\text { law, and stands as } \\
\text { evidence of a } \\
\text { continuing American } \\
\text { public policy } \\
\text { receptivity to ethics- } \\
\text { driven concerns. }\end{array}$ & $\begin{array}{l}\text { Journal of } \\
\text { Business } \\
\text { Ethics, 9(8): } \\
665-670\end{array}$ \\
\hline
\end{tabular}


Table 2 Articles on CSR, Transition Programs and The Local Community (continued)

\begin{tabular}{|c|c|c|c|c|c|}
\hline $\begin{array}{c}\text { Author(s) } \\
\text { (year) }\end{array}$ & $\begin{array}{c}\text { Research aims/ } \\
\text { objectives }\end{array}$ & $\begin{array}{c}\text { Theoretical perspective/ } \\
\text { framework }\end{array}$ & $\begin{array}{c}\text { Method } \\
\text { (empirical/theoretical) }\end{array}$ & Main findings & Journal \\
\hline $\begin{array}{l}\text { Ramsey } \\
(2014)\end{array}$ & $\begin{array}{l}\text { To examine the } \\
\text { grieving process } \\
\text { and experience of } \\
\text { unemployed people } \\
\text { and suggest } \\
\text { solutions to benefit } \\
\text { both the } \\
\text { organization and } \\
\text { the displaced } \\
\text { employee. }\end{array}$ & $\begin{array}{l}\text { Research related to } \\
\text { psychology of job loss. }\end{array}$ & $\begin{array}{l}\text { Narrative analysis and } \\
\text { personal experience of } \\
\text { a closure. }\end{array}$ & $\begin{array}{l}\text { The study highlights } \\
\text { that by acting } \\
\text { socially responsible, } \\
\text { the organization can } \\
\text { create good-will } \\
\text { among its employees } \\
\text { and the public. By } \\
\text { acting socially } \\
\text { responsible, the } \\
\text { organization should } \\
\text { provide assistance, } \\
\text { such as cancelling for } \\
\text { displaced workers. }\end{array}$ & $\begin{array}{l}\text { The } \\
\text { Psychologist- } \\
\text { Manager } \\
\text { Journal, 17(2): } \\
\text { 79-86. }\end{array}$ \\
\hline $\begin{array}{l}\text { Rydell and } \\
\text { Wigblad } \\
(2012)\end{array}$ & $\begin{array}{l}\text { The article focuses } \\
\text { on analysis of and } \\
\text { suggestions for } \\
\text { Corporate Social } \\
\text { Responsibility } \\
\text { (CSR) orientation } \\
\text { during plant } \\
\text { closure processes. }\end{array}$ & $\begin{array}{l}\text { Stakeholder theory and } \\
\text { research related to } \\
\text { strategic change and } \\
\text { plant closures. }\end{array}$ & $\begin{array}{l}\text { Multiple case studies. } \\
\text { Qualitative approach } \\
\text { with semi-structured } \\
\text { interviews and analysis } \\
\text { of company documents } \\
\text { etc. }\end{array}$ & $\begin{array}{l}\text { The findings suggest } \\
\text { that if coordination } \\
\text { of actions between } \\
\text { management } \\
\text { employee } \\
\text { representatives and } \\
\text { local community } \\
\text { come early during } \\
\text { the restructuring } \\
\text { process, it can adjust } \\
\text { business strategies } \\
\text { and create plans for } \\
\text { outreach HRM and } \\
\text { local community } \\
\text { activities. This, in } \\
\text { turn, could mitigate } \\
\text { the adverse effects of } \\
\text { the restructuring on } \\
\text { affected employees. }\end{array}$ & $\begin{array}{l}\text { Nordic Journal } \\
\text { of Working } \\
\text { Life Studies, } \\
\text { 2(3): 163-180. }\end{array}$ \\
\hline $\begin{array}{l}\text { Tang and } \\
\text { Crofford } \\
(1999)\end{array}$ & $\begin{array}{l}\text { To examine the } \\
\text { reactions and } \\
\text { feelings of } \\
\text { employees shortly } \\
\text { after the } \\
\text { announcement of a } \\
\text { plant closure. }\end{array}$ & $\begin{array}{l}\text { Research on displaced } \\
\text { workers. }\end{array}$ & $\begin{array}{l}\text { Survey with a 12-item } \\
\text { questionnaire, and five } \\
\text { percent of the total } \\
\text { workforce } \\
\text { participating. }\end{array}$ & $\begin{array}{l}\text { The result from the } \\
\text { survey shows that the } \\
\text { majority of the } \\
\text { employees had been } \\
\text { involved in job- } \\
\text { search activities } \\
\text { during the 6-month } \\
\text { advance notice } \\
\text { period, and some had } \\
\text { already been offered } \\
\text { jobs. Nevertheless, } \\
\text { many employees had } \\
\text { feelings of } \\
\text { resignation and } \\
\text { sadness. }\end{array}$ & $\begin{array}{l}\text { Journal of } \\
\text { Social } \\
\text { Psychology, } \\
\text { 139(1): 44-48. }\end{array}$ \\
\hline
\end{tabular}


Table 2 Articles on CSR, Transition Programs and The Local Community (continued)

\begin{tabular}{|c|c|c|c|c|c|}
\hline $\begin{array}{c}\text { Author(s) } \\
\text { (year) }\end{array}$ & $\begin{array}{l}\text { Research aims/ } \\
\text { objectives }\end{array}$ & $\begin{array}{c}\text { Theoretical perspective/ } \\
\text { framework }\end{array}$ & $\begin{array}{c}\text { Method } \\
\text { (empirical/theoretical) }\end{array}$ & Main findings & Journal \\
\hline $\begin{array}{l}\text { Carroll } \\
\text { (1984) }\end{array}$ & $\begin{array}{l}\text { Discussed how } \\
\text { management } \\
\text { should act and } \\
\text { manage public } \\
\text { affairs in order to } \\
\text { conduct a social } \\
\text { responsible } \\
\text { closedown. }\end{array}$ & $\begin{array}{l}\text { Research related to } \\
\text { management practices, } \\
\text { decision-making and } \\
\text { social responsibility in } \\
\text { connection to business } \\
\text { closures. }\end{array}$ & $\begin{array}{l}\text { Descriptive article. } \\
\text { Earlier closures cases } \\
\text { are discussed. }\end{array}$ & $\begin{array}{l}\text { Several areas of } \\
\text { management action } \\
\text { are discussed, such as } \\
\text { new ownership, } \\
\text { employee ownership, } \\
\text { community impact } \\
\text { analysis, advance } \\
\text { notice, outplacement } \\
\text { benefits, and gradual } \\
\text { phase outs and attract } \\
\text { new industry. }\end{array}$ & $\begin{array}{l}\text { California } \\
\text { Management } \\
\text { Review, 26(2): } \\
\text { 125-140. }\end{array}$ \\
\hline $\begin{array}{l}\text { Littlewood } \\
(2014)\end{array}$ & $\begin{array}{l}\text { To investigate CSR } \\
\text { in relation to } \\
\text { mining community } \\
\text { development, } \\
\text { sustainability and } \\
\text { viability in } \\
\text { Namibia, and the } \\
\text { complexities which } \\
\text { surround the } \\
\text { decision-making } \\
\text { about affected } \\
\text { communities after } \\
\text { mining. }\end{array}$ & $\begin{array}{l}\text { Research on CSR, and } \\
\text { literature related to } \\
\text { mining and development. }\end{array}$ & $\begin{array}{l}\text { Case studies of three } \\
\text { communities. The } \\
\text { author used qualitative } \\
\text { research methods, such } \\
\text { as } 90 \text { key informant } \\
\text { interview, focus groups } \\
\text { and field note-taking. } \\
\text { In addition, secondary } \\
\text { document analyses and } \\
\text { material analyses were } \\
\text { carried out. }\end{array}$ & $\begin{array}{l}\text { The findings suggest } \\
\text { that Namibia needs } \\
\text { to strengthen, and } \\
\text { devise more } \\
\text { comprehensive, mine } \\
\text { closure legalization. } \\
\text { Several } \\
\text { recommendations } \\
\text { and alternatives for } \\
\text { governments and } \\
\text { companies in similar } \\
\text { situations are } \\
\text { provided. }\end{array}$ & $\begin{array}{l}\text { Journal of } \\
\text { Business } \\
\text { Ethics, 120(1): } \\
\text { 39-63. }\end{array}$ \\
\hline $\begin{array}{l}\text { McMahon } \\
(1999)\end{array}$ & $\begin{array}{l}\text { Examined a plant } \\
\text { closure and how } \\
\text { the community } \\
\text { responded during } \\
\text { the process. }\end{array}$ & $\begin{array}{l}\text { Research on business } \\
\text { ethics and CSR. }\end{array}$ & Qualitative case study. & $\begin{array}{l}\text { The findings show } \\
\text { that Chrysler } \\
\text { changed their } \\
\text { strategy during the } \\
\text { course of } \\
\text { restructuring from } \\
\text { being socially } \\
\text { irresponsible to } \\
\text { becoming socially } \\
\text { responsive through } \\
\text { offering generous } \\
\text { financial and social } \\
\text { support and } \\
\text { providing the city } \\
\text { with new } \\
\text { opportunities. This } \\
\text { was due to external } \\
\text { reactions and } \\
\text { pressure. }\end{array}$ & $\begin{array}{l}\text { Journal of } \\
\text { Business } \\
\text { Ethics, } \\
\text { 20(2):101-111. }\end{array}$ \\
\hline
\end{tabular}


Table 2 Articles on CSR, Transition Programs and The Local Community (continued)

\begin{tabular}{|c|c|c|c|c|c|}
\hline $\begin{array}{l}\text { Author(s) } \\
\text { (year) }\end{array}$ & $\begin{array}{l}\text { Research aims/ } \\
\text { objectives }\end{array}$ & $\begin{array}{l}\text { Theoretical perspective/ } \\
\text { framework }\end{array}$ & $\begin{array}{c}\text { Method } \\
\text { (empirical/theoretical) }\end{array}$ & Main findings & Journal \\
\hline $\begin{array}{l}\text { Browne, } \\
\text { Stehlik \& } \\
\text { Buckley } \\
(2011)\end{array}$ & $\begin{array}{l}\text { The article seeks to } \\
\text { document } \\
\text { reflections from a } \\
\text { rapid rural } \\
\text { appraisal } \\
\text { conducted in a } \\
\text { remote rural area in } \\
\text { Western Australia, } \\
\text { after the Nickel } \\
\text { Operation was } \\
\text { "mothballed" } 9 \\
\text { months into a } \\
\text { projected 25-year } \\
\text { lifespan. }\end{array}$ & The social licence model. & $\begin{array}{l}\text { Case study. Semi- } \\
\text { structured interview } \\
\text { questionnaire was } \\
\text { conducted with } \\
\text { different members of } \\
\text { the local community, } \\
\text { and a forum with } \\
\text { farmers from the area } \\
\text { directly next to the } \\
\text { mine site. }\end{array}$ & $\begin{array}{l}\text { The article illustrate } \\
\text { how companies can } \\
\text { involve non- } \\
\text { contractual partners } \\
\text { such as local } \\
\text { communities when } \\
\text { companies are doing } \\
\text { well but are not } \\
\text { legally bound to } \\
\text { assume responsibility } \\
\text { when they are doing } \\
\text { bad. }\end{array}$ & $\begin{array}{l}\text { Local } \\
\text { Environment: } \\
\text { The } \\
\text { International } \\
\text { Journal of } \\
\text { Justice and } \\
\text { Sustainability, } \\
\text { 16(7): 707- } \\
725 .\end{array}$ \\
\hline $\begin{array}{l}\text { Ahlstrand } \\
(2010)\end{array}$ & $\begin{array}{l}\text { To understand the } \\
\text { reasons for } \\
\text { Ericsson } \\
\text { Telecom's } \\
\text { accountability } \\
\text { when it laid off } \\
\text { about } 23,000 \\
\text { employees in } \\
\text { Sweden in the } \\
\text { beginning of the } \\
\text { 2000s. }\end{array}$ & $\begin{array}{l}\text { New institutional } \\
\text { organisation theory. }\end{array}$ & $\begin{array}{l}\text { Case study. Qualitative } \\
\text { approach with } \\
\text { interviews and analysis } \\
\text { of texts and company } \\
\text { documents. }\end{array}$ & $\begin{array}{l}\text { Ericsson was in a } \\
\text { delicate process of } \\
\text { change and } \\
\text { especially dependent } \\
\text { on social legitimacy } \\
\text { for their operations. }\end{array}$ & $\begin{array}{l}\text { Economic and } \\
\text { Industrial } \\
\text { Democracy, } \\
\text { 31(4): 537-555 }\end{array}$ \\
\hline $\begin{array}{l}\text { Rydell and } \\
\text { Wigblad } \\
(2011)\end{array}$ & $\begin{array}{l}\text { To examine two } \\
\text { closure cases and } \\
\text { analyze how the } \\
\text { restructuring } \\
\text { process can be } \\
\text { improved by } \\
\text { company-level } \\
\text { flexicurity. }\end{array}$ & $\begin{array}{l}\text { Research on flexicurity, } \\
\text { temporary employment } \\
\text { and CSR. }\end{array}$ & $\begin{array}{l}\text { Qualitative case study. } \\
\text { Semi-structured } \\
\text { interviews with top } \\
\text { management, plant } \\
\text { management, trade } \\
\text { union representatives } \\
\text { and representatives of } \\
\text { the municipalities. The } \\
\text { interviews were } \\
\text { complemented with } \\
\text { company documents, } \\
\text { minutes and informal } \\
\text { contact with } \\
\text { participants. }\end{array}$ & $\begin{array}{l}\text { The findings indicate } \\
\text { that management and } \\
\text { labour unions create } \\
\text { company flexicurity } \\
\text { by exchanging } \\
\text { numerical flexibility, } \\
\text { through temporary } \\
\text { workers with } \\
\text { strategic CSR in } \\
\text { order to create a } \\
\text { restructuring process } \\
\text { that benefits both } \\
\text { parties (employees } \\
\text { and management), as } \\
\text { well as the local } \\
\text { community. }\end{array}$ & $\begin{array}{l}\text { Transfer: } \\
\text { European } \\
\text { Review of } \\
\text { Labour and } \\
\text { Research, } \\
\text { 17(4): } 547- \\
562 .\end{array}$ \\
\hline $\begin{array}{l}\text { Wigblad } \\
\text { (1995) }\end{array}$ & $\begin{array}{l}\text { To present a } \\
\text { model, which a } \\
\text { community can use } \\
\text { to offset the } \\
\text { employment losses } \\
\text { associated with the } \\
\text { closure of a large } \\
\text { employer }\end{array}$ & $\begin{array}{l}\text { Literature related to } \\
\text { organizational decline, } \\
\text { closures and social } \\
\text { responsibility. }\end{array}$ & $\begin{array}{l}\text { Case study. Qualitative } \\
\text { approach with semi- } \\
\text { structured interviews } \\
\text { with management, } \\
\text { trade union } \\
\text { representatives and } \\
\text { representatives for the } \\
\text { local community. }\end{array}$ & $\begin{array}{l}\text { The author develops } \\
\text { a model that shows } \\
\text { that a long } \\
\text { closedown period } \\
\text { combined with } \\
\text { cooperation approach } \\
\text { between three } \\
\text { parties; management, } \\
\text { labor and } \\
\text { government can } \\
\text { mitigate the adverse } \\
\text { effects. The model is } \\
\text { sensitive to the } \\
\text { business cycle. }\end{array}$ & $\begin{array}{l}\text { The Journal of } \\
\text { Socio- } \\
\text { Economics, } \\
\text { 24(3): } 463- \\
475 .\end{array}$ \\
\hline
\end{tabular}




\section{CSR and Business Strategy}

Seven articles in this study covered the theme of CSR and business strategy (Table 3) by focusing on business strategy development in relation to CSR during downsizing and closure processes. These strategies often include several management choices and tactics that often involve the application of more than one single strategy during the process (cf. Karlsson, 2013). However, the ways in which business strategies shape and evolve depend on both internal and external reasons. For instance, the greater social responsibility taken on by the telecom company Ericsson, when restructuring at the beginning of the twenty-first century, was based on its decision to meet strong demands from authoritative actors in its environment and maintain legitimacy by considering prevailing societal expectations regarding the company's behaviour (Ahlstrand, 2010). However, business strategies of companies that are not assuming social responsibility are also made visible. Business strategies shaped by the financialized approach to shareholder value means a mismatch between treating CSR as a business strategy and, on the other hand, employees as stakeholders (Jones \& Nisbet, 2011). In these cases, the corporate brand image and reputation are prioritized instead of trying to achieve long-term sustainable operations and stakeholder partnerships, according to Jones and Nispet.

Suggestions on how business strategies contribute to socially responsible closures and downsizings take different routes. For instance, strategies for downsizing should take into account that a contradiction between goals on profits and responsibilities is not automatically assumed (Kothen, McKinley, \& Scherer, 1999). Human resource management programs can integrate both of these. The auto manufacturer Volkswagen cut working hours instead of mass dismissals, which, according to Kothen, McKinley and Scherer, was a correct decision, since it considered several stakeholders' interests:

The advantage of assuring the employees their jobs is quite obvious: Uncertainty about losing one's job and not finding another job in the structurally weaker regions around the Volkswagen plants is eliminated. [...] The advantage for the company is obvious: cost reduction. [...] The benefit for society is not only the prevention of mass dismissals but also the effect on the labour market. In this particular case, the dismissal of 30,000 employees would have cost the state about 2.3 billion DM per year in unemployment benefits, social insurance, and tax deficits (Kothen, McKinley, \& Scherer, 1999: 282-283).

The findings also recommend that companies develop business strategies for CSR orientation early in restructuring processes (Rydell \& Wigblad, 2012). Coordination of CSR actions from the very beginning increases the scope of action and facilitates the adjustment of the business strategies and plans to develop HRM and local community 
activities. Furthermore, the importance of more comprehensive CSR models for downsizing and closures has been underlined. For instance, Stjernberg and Tillberg (1998) argued that strategies need to be holistic to handle downsizing in a socially responsible way, emphasizing the importance of simultaneously considering the procedures chosen as well as political, organizational and individual aspects. Bracker and Kinicki (1988), proposed a process model depicting the manner in which organizations formulate and implement managerial strategies in response to an impending plant closing. The model, they claim, addresses the general context of the plant closure process and organizations' different strategic responses to such development. Hereby, the model is supposed to support organizations in being socially responsive when deciding to close a plant and to help organizational planners and management systematically examine the effect of a plant closure as well support the process of developing procedures to close and open facilities (Bracker \& Kinicki 1988: 211).

Table 3 Articles on CSR and Business Strategy

\begin{tabular}{|c|c|c|c|c|c|}
\hline $\begin{array}{l}\text { Author(s) } \\
\text { (year) }\end{array}$ & $\begin{array}{l}\text { Research } \\
\text { aims/objectives }\end{array}$ & $\begin{array}{l}\text { Theoretical } \\
\text { perspective/framework }\end{array}$ & $\begin{array}{l}\text { Method } \\
\text { (empirical/theoretical) }\end{array}$ & Main findings & Journal \\
\hline $\begin{array}{l}\text { Ahlstrand } \\
(2010)\end{array}$ & $\begin{array}{l}\text { To understand the } \\
\text { reasons for Ericsson } \\
\text { Telecom's } \\
\text { accountability when it } \\
\text { laid off about } 23,000 \\
\text { employees in Sweden } \\
\text { in the beginning of } \\
\text { the } 2000 \text { s. }\end{array}$ & $\begin{array}{l}\text { New institutional } \\
\text { organisation theory. }\end{array}$ & $\begin{array}{l}\text { Case study. Qualitative } \\
\text { approach with } \\
\text { interviews and analysis } \\
\text { of texts and company } \\
\text { documents. }\end{array}$ & $\begin{array}{l}\text { Ericsson was in a delicate } \\
\text { process of change and } \\
\text { especially dependent on } \\
\text { social legitimacy for their } \\
\text { operations. }\end{array}$ & $\begin{array}{l}\text { Economic and } \\
\text { Industrial } \\
\text { Democracy, } \\
\text { 31(4): 537-555. }\end{array}$ \\
\hline $\begin{array}{l}\text { Stjernberg } \\
\text { and Tillberg } \\
(1998)\end{array}$ & $\begin{array}{l}\text { To understand what } \\
\text { happens to directly } \\
\text { and indirectly } \\
\text { concerned employees } \\
\text { in the process of } \\
\text { downsizing. Can } \\
\text { downsizing be } \\
\text { handled in a socially } \\
\text { responsible way? If } \\
\text { so, how? }\end{array}$ & $\begin{array}{l}\text { Theories on ethics, } \\
\text { perceived fairness, } \\
\text { individual stress, identity } \\
\text { and psychological } \\
\text { dynamics in crisis } \\
\text { situations. }\end{array}$ & $\begin{array}{l}\text { Case studies. } \\
\text { Qualitative approach. }\end{array}$ & $\begin{array}{l}\text { The authors suggest that a } \\
\text { holistic perspective on } \\
\text { downsizing and social } \\
\text { responsibility is needed, } \\
\text { where procedures chosen } \\
\text { and political, } \\
\text { organizational, and } \\
\text { individual aspects need to } \\
\text { be considered together. }\end{array}$ & $\begin{array}{l}\text { European } \\
\text { journal of work } \\
\text { and } \\
\text { organizational } \\
\text { psychology, } \\
7(3): 355-371 .\end{array}$ \\
\hline $\begin{array}{l}\text { Karlsson } \\
(2013)\end{array}$ & $\begin{array}{l}\text { To clarify and discuss } \\
\text { the various ways } \\
\text { firms can make } \\
\text { workforce reductions. } \\
\text { The research question } \\
\text { is: How do managers } \\
\text { perceive the options } \\
\text { for downsizing and } \\
\text { why do they } \\
\text { implement a } \\
\text { particular mix of } \\
\text { measures before } \\
\text { another? }\end{array}$ & $\begin{array}{l}\text { Research on workforce } \\
\text { reduction strategies. }\end{array}$ & $\begin{array}{l}\text { Case study of the } \\
\text { Swedish Tobacco } \\
\text { Monopoly in the 1920s. } \\
\text { Qualitative approach. }\end{array}$ & $\begin{array}{l}\text { Findings show that there } \\
\text { are basically three } \\
\text { strategies for reducing the } \\
\text { workforce, but more than } \\
\text { one strategy can be } \\
\text { applied simultaneously } \\
\text { and each of these } \\
\text { strategies can be } \\
\text { implemented by using a } \\
\text { range of tactics. }\end{array}$ & $\begin{array}{l}\text { Enterprise \& } \\
\text { Society, 14(4): } \\
829-853 .\end{array}$ \\
\hline
\end{tabular}


Table 3 Articles on CSR and Business Strategy (continued)

\begin{tabular}{|c|c|c|c|c|c|}
\hline $\begin{array}{l}\text { Author(s) } \\
\text { (year) }\end{array}$ & $\begin{array}{l}\text { Research } \\
\text { aims/objectives }\end{array}$ & $\begin{array}{l}\text { Theoretical } \\
\text { perspective/framework }\end{array}$ & $\begin{array}{l}\text { Method } \\
\text { (empirical/theoretical) }\end{array}$ & Main findings & Journal \\
\hline $\begin{array}{l}\text { Jones and } \\
\text { Nisbet } \\
(2011)\end{array}$ & $\begin{array}{l}\text { To examine the scope } \\
\text { of CSR amongst a test } \\
\text { case of transnational } \\
\text { food manufacturing } \\
\text { corporations. }\end{array}$ & $\begin{array}{l}\text { Theory on } \\
\text { 'financialization', and } \\
\text { research on contradiction } \\
\text { of CSR. }\end{array}$ & $\begin{array}{l}\text { Two case studies with } \\
\text { qualitative approach. } \\
\text { Semi-structured } \\
\text { interviews with senior } \\
\text { management and/or } \\
\text { operations personnel } \\
\text { from each company, } \\
\text { and interviews with } \\
\text { industry participants in } \\
\text { local and national trade } \\
\text { union organizations, as } \\
\text { well as internal } \\
\text { documents and some } \\
\text { publicly available } \\
\text { reports. }\end{array}$ & $\begin{array}{l}\text { The study highlights that } \\
\text { business strategies shaped } \\
\text { by the financialized } \\
\text { approach to shareholder } \\
\text { value means an } \\
\text { incompatibility between } \\
\text { treating CSR as a business } \\
\text { strategy and, on the other } \\
\text { hand, employees as } \\
\text { stakeholders. The } \\
\text { corporate brand image and } \\
\text { reputation are prioritized } \\
\text { rather than attempting } \\
\text { sustainable operations and } \\
\text { stakeholder partnerships. }\end{array}$ & $\begin{array}{l}\text { Socio- } \\
\text { Economic } \\
\text { Review, 9: 287- } \\
314 .\end{array}$ \\
\hline $\begin{array}{l}\text { Rydell and } \\
\text { Wigblad } \\
(2012)\end{array}$ & $\begin{array}{l}\text { The article focuses on } \\
\text { analysis of and } \\
\text { suggestions for } \\
\text { Corporate Social } \\
\text { Responsibility (CSR) } \\
\text { orientation during } \\
\text { plant closure } \\
\text { processes. }\end{array}$ & $\begin{array}{l}\text { Stakeholder theory and } \\
\text { research on strategic } \\
\text { change and plant } \\
\text { closures. }\end{array}$ & $\begin{array}{l}\text { Multiple case studies. } \\
\text { Qualitative approach } \\
\text { with semi-structured } \\
\text { interviews and analysis } \\
\text { of company documents } \\
\text { etc. }\end{array}$ & $\begin{array}{l}\text { The findings suggest that } \\
\text { if coordination of actions } \\
\text { between management } \\
\text { employee representatives } \\
\text { and local community } \\
\text { come early during the } \\
\text { restructuring process, it } \\
\text { can adjust business } \\
\text { strategies and create plans } \\
\text { for outreach HRM and } \\
\text { local community } \\
\text { activities. This, in turn, } \\
\text { could mitigate the adverse } \\
\text { effects of the restructuring } \\
\text { on affected employees. }\end{array}$ & $\begin{array}{l}\text { Nordic Journal } \\
\text { of Working Life } \\
\text { Studies, 2(3): } \\
\text { 163-180. }\end{array}$ \\
\hline $\begin{array}{l}\text { Bracker and } \\
\text { Kinicki } \\
(1988)\end{array}$ & $\begin{array}{l}\text { This article focuses } \\
\text { on developing a } \\
\text { process model of the } \\
\text { manner by which } \\
\text { organizations } \\
\text { formulate and } \\
\text { implement } \\
\text { managerial strategies } \\
\text { in response to an } \\
\text { impending plant } \\
\text { closure. }\end{array}$ & $\begin{array}{l}\text { Theoretical } \\
\text { underpinnings derived } \\
\text { from the strategic } \\
\text { management and social } \\
\text { responsibility literature. }\end{array}$ & Conceptual article. & $\begin{array}{l}\text { The process model that is } \\
\text { developed in the article } \\
\text { takes the overall context } \\
\text { of the closure process into } \\
\text { account, as well as } \\
\text { identifying different } \\
\text { strategic responses that an } \\
\text { organization may follow, } \\
\text { and the nature and } \\
\text { philosophy of its social } \\
\text { responsiveness. }\end{array}$ & $\begin{array}{l}\text { Employee } \\
\text { Responsibilities } \\
\text { and Rights } \\
\text { Journal, 1(3): } \\
\text { 201-213. }\end{array}$ \\
\hline $\begin{array}{l}\text { Kothen, } \\
\text { McKinley } \\
\text { and Scherer } \\
\text { (1999) }\end{array}$ & $\begin{array}{l}\text { To present the case of } \\
\text { a German company } \\
\text { that has resisted the } \\
\text { taken-for-grantedness } \\
\text { of downsizing, and } \\
\text { devised alternative } \\
\text { strategies for } \\
\text { achieving cost } \\
\text { reduction and } \\
\text { profitability } \\
\text { improvement. }\end{array}$ & $\begin{array}{l}\text { Three complementary } \\
\text { perspectives: the } \\
\text { economic perspective, } \\
\text { the institutional } \\
\text { perspective, and the } \\
\text { socio-cognitive } \\
\text { perspective. }\end{array}$ & $\begin{array}{l}\text { Qualitative approach } \\
\text { with a variety of data } \\
\text { sources, such as the } \\
\text { business press and } \\
\text { interviews with } \\
\text { members of the works } \\
\text { council of VW. }\end{array}$ & $\begin{array}{l}\text { The findings suggest that } \\
\text { profits and social } \\
\text { responsibility do not } \\
\text { necessarily have to be } \\
\text { competing goals; instead } \\
\text { they can sometimes be } \\
\text { jointly accommodated by } \\
\text { using appropriate HRM- } \\
\text { programs. }\end{array}$ & $\begin{array}{l}\text { M@n@gement, } \\
\text { 2(3): 263-286. }\end{array}$ \\
\hline
\end{tabular}

\section{CSR, Power and Reputation}

Five articles were grouped under the theme of CSR, power and reputation (Table 4). Two of the above-mentioned articles addressing power relations, namely Ahlstrand (2010) and McMahon (1999), illustrate how pressure from authoritative actors outside the company caused a shift in company strategy from being socially irresponsible to assuming social responsibility. Articles dealing with CSR and reputation strengthen 
this argument, as they show that 'bad behavior' may encourage customers to conduct business with other companies, potential employees to be less interested in working for the company, and shareholders to lose confidence in the company (cf. Ahlstrand, 2010). Downsizing is, for example, often perceived as just a bad behaviour in terms of being less socially responsible (Karake, 1998). Zyglidopoulos (2004) argued that higher financial performance contributes to a greater negative effect of downsizing on a firm's reputation. The damaged reputation could depend on several factors, including the fact that downsizing and closure decisions violate social contracts and therefore create a negative image in the public eye due to the possible effects on people and local communities, not least since plant closure and major downsizing events often receive the attention of the public and the mass media (cf. Ahlstrand, 2010; McMahon, 1999). Thus, corporate social responsibility may be a business strategy for reducing the effect of reputational damage on the corporate brand image (Jones \& Nisbet, 2011).

The review also reveals other ways of perceiving power relations. Bergström and Diedrich (2011) examined the micro-policy processes in connection with mass redundancies and the ways in which corporate representatives manage to enrol and mobilize stakeholders into accepting the corporate's definition of social responsibility. They found that instead of responding to the stakeholders' interest, the corporation shapes and transforms them; thus, exercising CSR in redundant processes "may be regarded as reinforcing the powerful position of the corporation" (Bergström \& Diedrich, 2011: 915). The power relations of the corporation are also visible in the study by Mayes, Pini and McDonald (2012) who drew on the notion of dialogue with vulnerable groups. They argued that the CSR discourse and vulnerable other dialogue affirm the dominance of business interests and "co-opt vulnerable others in the pursuit of these interests" (Mayes et al., 2012: 840). 
Table 4 Articles on CSR, Power and Reputation

\begin{tabular}{|c|c|c|c|c|c|}
\hline $\begin{array}{l}\text { Author(s) } \\
\text { (year) }\end{array}$ & $\begin{array}{l}\text { Research } \\
\text { aims/objectives }\end{array}$ & $\begin{array}{l}\text { Theoretical } \\
\text { perspective/framework }\end{array}$ & $\begin{array}{l}\text { Method } \\
\text { (empirical/theoretical) }\end{array}$ & Main findings & Journal \\
\hline $\begin{array}{l}\text { Mayes, Pini } \\
\text { and McDonald } \\
(2012)\end{array}$ & $\begin{array}{l}\text { This article } \\
\text { examines the } \\
\text { possibilities for } \\
\text { and conditions } \\
\text { underpinning } \\
\text { corporate dialogue } \\
\text { with marginalized } \\
\text { stakeholders. }\end{array}$ & $\begin{array}{l}\text { Research on the dialogue } \\
\text { with vulnerable others, } \\
\text { and discourse analysis. }\end{array}$ & $\begin{array}{l}\text { Case study consisting } \\
\text { of an assemblage of } \\
\text { corporate public } \\
\text { communications, and } \\
\text { semi-structured } \\
\text { interviews with } \\
\text { vulnerable others. }\end{array}$ & $\begin{array}{l}\text { The findings suggest that } \\
\text { CSR discourse and } \\
\text { vulnerable-other dialogue } \\
\text { affirms the primacy of } \\
\text { business interests, as well } \\
\text { as co-opts vulnerable } \\
\text { others in the pursuit of } \\
\text { these interests. }\end{array}$ & $\begin{array}{l}\text { Organization, } \\
20(6): 840- \\
859 .\end{array}$ \\
\hline $\begin{array}{l}\text { Bergström and } \\
\text { Diedrich } \\
(2011)\end{array}$ & $\begin{array}{l}\text { The article } \\
\text { critically } \\
\text { investigates the } \\
\text { claims made by } \\
\text { earlier research } \\
\text { that companies } \\
\text { exercise CSR by } \\
\text { responding to } \\
\text { stakeholders' } \\
\text { interest. The article } \\
\text { seeks to answer the } \\
\text { research question: } \\
\text { How do companies } \\
\text { exercise CSR } \\
\text { when influencing } \\
\text { relationships in } \\
\text { their embedded } \\
\text { networks of actors? }\end{array}$ & Action-network theory. & $\begin{array}{l}\text { Qualitative case study. } \\
\text { The data was gathered } \\
\text { through observations, } \\
\text { interviews, and } \\
\text { document analysis. }\end{array}$ & $\begin{array}{l}\text { The findings show that } \\
\text { corporate representatives } \\
\text { managed to enroll and } \\
\text { mobilize a network of } \\
\text { actors to being faithful, } \\
\text { and defending, the } \\
\text { company's definition of } \\
\text { social responsibility, } \\
\text { during the restructuring } \\
\text { process. }\end{array}$ & $\begin{array}{l}\text { Organization } \\
\text { Studies, 32(7): } \\
897-919 .\end{array}$ \\
\hline $\begin{array}{l}\text { Jones and } \\
\text { Nisbet } \\
(2011)\end{array}$ & $\begin{array}{l}\text { To examine the } \\
\text { scope of CSR in a } \\
\text { test case of } \\
\text { transnational food } \\
\text { manufacturing } \\
\text { corporations. }\end{array}$ & $\begin{array}{l}\text { Theory on } \\
\text { 'financialization', and } \\
\text { research on contradiction } \\
\text { of CSR. }\end{array}$ & $\begin{array}{l}\text { Two case studies with } \\
\text { qualitative approach. } \\
\text { Semi-structured } \\
\text { interviews with senior } \\
\text { management and/or } \\
\text { operations personnel } \\
\text { from each company, } \\
\text { and interviews with } \\
\text { industry participants in } \\
\text { local and national trade } \\
\text { union organizations, as } \\
\text { well as internal } \\
\text { documents and some } \\
\text { publicly available } \\
\text { reports. }\end{array}$ & $\begin{array}{l}\text { The study highlights that } \\
\text { business strategies shaped } \\
\text { by the financialized } \\
\text { approach to shareholder } \\
\text { value means an } \\
\text { incompatibility between } \\
\text { treating CSR as a business } \\
\text { strategy and, on the other } \\
\text { hand, employees as } \\
\text { stakeholders. The } \\
\text { corporate brand image and } \\
\text { reputation are prioritized } \\
\text { rather than attempting } \\
\text { sustainable operations and } \\
\text { stakeholder partnerships. }\end{array}$ & $\begin{array}{l}\text { Socio- } \\
\text { Economic } \\
\text { Review, 9: } \\
\text { 287-314. }\end{array}$ \\
\hline Karake (1998) & $\begin{array}{l}\text { To empirically test } \\
\text { the relationship } \\
\text { between a firm's } \\
\text { social } \\
\text { responsibility } \\
\text { (CSR) } \\
\text { performance, } \\
\text { which is measured } \\
\text { by the firm's } \\
\text { reputation index, } \\
\text { on the one hand, } \\
\text { and the degree of } \\
\text { downsizing of } \\
\text { employees and a } \\
\text { firm's } \\
\text { discriminatory } \\
\text { practice, on the } \\
\text { other hand. }\end{array}$ & $\begin{array}{l}\text { Literature related to } \\
\text { corporate restructuring } \\
\text { and downsizing, as well } \\
\text { as corporate social } \\
\text { responsibility. }\end{array}$ & $\begin{array}{l}\text { Statistical analysis } \\
\text { through Ordinary Least } \\
\text { Squared (OLS) multiple } \\
\text { regression. The sample } \\
\text { consists of } 178 \text { large, } \\
\text { publicity-held US- } \\
\text { based corporations, } \\
\text { which announced that } \\
\text { they would downsize } \\
\text { during 1990-1992. }\end{array}$ & $\begin{array}{l}\text { The results support the } \\
\text { hypothesis that companies } \\
\text { who cut jobs and lay-off } \\
\text { workers are perceived as } \\
\text { being less socially } \\
\text { responsible. In addition, } \\
\text { the results support a } \\
\text { positive association } \\
\text { between a firm's social } \\
\text { performances (measured } \\
\text { by a company's reputation } \\
\text { index) and its financial } \\
\text { performance, as measured } \\
\text { by its return on equity. }\end{array}$ & $\begin{array}{l}\text { Management } \\
\text { Decision } \\
\text { 36(3): 206- } \\
216 .\end{array}$ \\
\hline
\end{tabular}


Table 4 Articles on CSR, Power and Reputation (continued)

\begin{tabular}{|c|c|c|c|c|c|}
\hline $\begin{array}{l}\text { Author(s) } \\
\text { (year) }\end{array}$ & $\begin{array}{l}\text { Research } \\
\text { aims/objectives }\end{array}$ & $\begin{array}{l}\text { Theoretical } \\
\text { perspective/framework }\end{array}$ & $\begin{array}{l}\text { Method } \\
\text { (empirical/theoretical) }\end{array}$ & Main findings & Journal \\
\hline $\begin{array}{l}\text { Zyglidopoulos } \\
\text { (2004) }\end{array}$ & $\begin{array}{l}\text { To investigate the } \\
\text { impact of } \\
\text { downsizing on a } \\
\text { firm's corporate } \\
\text { social } \\
\text { performance. }\end{array}$ & $\begin{array}{l}\text { Literature related to } \\
\text { downsizing, corporate } \\
\text { reputation and social } \\
\text { responsibility. }\end{array}$ & $\begin{array}{l}\text { Multivariate regression. } \\
\text { Two data sources were } \\
\text { used: Wall Street } \\
\text { Journal Index and } \\
\text { Fortune's AMAC } \\
\text { survey. }\end{array}$ & $\begin{array}{l}\text { The findings suggest that } \\
\text { downsizing seem to } \\
\text { negatively impact a firm's } \\
\text { reputation for corporate } \\
\text { social performance } \\
\text { (RCSP). However, when } \\
\text { taking the kind of } \\
\text { managerial action that led } \\
\text { to downsizing into } \\
\text { account, the impact of } \\
\text { downsizing seems to be } \\
\text { different between the } \\
\text { stakeholder groups which } \\
\text { were investigated, namely } \\
\text { financial analysts and } \\
\text { industry and executives. In } \\
\text { addition, the study reveals } \\
\text { that a higher financial } \\
\text { performance prior to } \\
\text { downsizing results in a } \\
\text { greater negative impact on } \\
\text { the firm's RSCP. }\end{array}$ & $\begin{array}{l}\text { Journal of } \\
\text { Public Affairs, } \\
\text { 4(1): 11-25. }\end{array}$ \\
\hline
\end{tabular}

\section{Other Articles on CSR in Connection with Business Closures and Downsizing}

Three other articles have been identified that address social responsibility in connection with closedowns or downsizing (Table 5). Two of the articles provide an ethical framework for downsizing events (Van Buren, 2000; Hopkins \& Hopkins, 1999). Van Buren (2000) was interested in psychological and social contracts that address how downsizing events are judged. The researcher proposed that implied contracts bind the actions of employers and that employment is not solely a private matter. Furthermore, Hopkins and Hopkins (1999) explored three different dimensions of downsizing, such as communication timing, method and content. For the employees to consider downsizing ethical, it should be implemented on a day other than a major holiday. Importantly, the management should inform the employees about the downsizing, give sufficient advance notice concerning redundancies, and a clear message regarding the reason for the downsizing decision (Hopkins \& Hopkins, 1999).

The third article had another focus, investigating the "closedown effect," that is, an increase in productivity during plant closing processes, and whether a socially responsible manner from management can explain this effect by investigating four non-social responsible cases (Hansson \& Wigblad, 2006). The authors concluded that the closedown effect appears during the countdown period, which is the phase between the negotiations are completed and the closing day, even in cases where management has not encountered social responsibility (Hansson \& Wigblad, 2006). 
Table 5 Other Articles on CSR in Connection to Downsizing and Business Closures

\begin{tabular}{|c|c|c|c|c|c|}
\hline $\begin{array}{l}\text { Author(s) } \\
\text { (year) }\end{array}$ & $\begin{array}{l}\text { Research } \\
\text { aims/objectives }\end{array}$ & $\begin{array}{l}\text { Theoretical } \\
\text { perspective/framework }\end{array}$ & $\begin{array}{l}\text { Method } \\
\text { (empirical/theoretical) }\end{array}$ & Main findings & Journal \\
\hline $\begin{array}{l}\text { Hopkins and } \\
\text { Hopkins } \\
(1999)\end{array}$ & $\begin{array}{l}\text { To identify and } \\
\text { explore three } \\
\text { dimensions of } \\
\text { downsizing }\end{array}$ & $\begin{array}{l}\text { Research on ethics in } \\
\text { downsizing }\end{array}$ & $\begin{array}{l}\text { Survey and statistical } \\
\text { analysis. }\end{array}$ & $\begin{array}{l}\text { Factors, like timing of } \\
\text { communication, who } \\
\text { delivers the message } \\
\text { (management), a clear } \\
\text { message that explains the } \\
\text { reason, and advance } \\
\text { notice contribute to how } \\
\text { employees are to } \\
\text { consider the downsizing, } \\
\text { as well as ethical factors }\end{array}$ & $\begin{array}{l}\text { Journal of } \\
\text { Business } \\
\text { Ethics, 18(2): } \\
\text { 145-156. }\end{array}$ \\
\hline $\begin{array}{l}\text { Van Buren } \\
(2000)\end{array}$ & $\begin{array}{l}\text { To examine how } \\
\text { downsizing violates } \\
\text { implied social and } \\
\text { psychological } \\
\text { contracts. }\end{array}$ & $\begin{array}{l}\text { Psychological contract } \\
\text { and social contract } \\
\text { theory }\end{array}$ & Conceptual article. & $\begin{array}{l}\text { The article provides an } \\
\text { ethical framework for } \\
\text { downsizing ethics. The } \\
\text { author demonstrates that } \\
\text { downsizing events are } \\
\text { not morally neutral. }\end{array}$ & $\begin{array}{l}\text { Journal of } \\
\text { Business } \\
\text { Ethics, 25(3): } \\
\text { 205-219 }\end{array}$ \\
\hline $\begin{array}{l}\text { Hansson and } \\
\text { Wigblad } \\
(2006)\end{array}$ & $\begin{array}{l}\text { To analyze } \\
\text { organizational } \\
\text { performance during } \\
\text { plant closure } \\
\text { processes. }\end{array}$ & $\begin{array}{l}\text { Research on } \\
\text { organizational decline } \\
\text { and closedowns. }\end{array}$ & $\begin{array}{l}\text { Multiple case studies. } \\
\text { Interviews and statistical } \\
\text { analysis of productivity. }\end{array}$ & $\begin{array}{l}\text { The closedown effect } \\
\text { appears in both social and } \\
\text { non-social responsible } \\
\text { closedowns and can be } \\
\text { expected during the } \\
\text { countdown period. }\end{array}$ & $\begin{array}{l}\text { International } \\
\text { Journal of } \\
\text { Human } \\
\text { Resource } \\
\text { Management, } \\
\text { 17(5): } 938- \\
\text { 958. }\end{array}$ \\
\hline
\end{tabular}

\section{CONCLUDING DISCUSSION}

The aim of this study was to review the research on the relation of the CSR with business closures and downsizing to gain an understanding of the current body of knowledge and thus to identify knowledge gaps. The systematic review of the existing literature involved a thorough reading and categorizing of 24 refereed articles into four themes representing the existing knowledge base: CSR, transition programs and the local community; CSR and strategy; CSR, power and reputation; and other articles on CSR in connection with business closures and downsizing. This classification helped us identify three knowledge gaps.

First, the review indicated that the answers to why companies assume CSR were scattered. Incentives concerned not only one single and easy identifiable motive, but rather a web of intertwined reasons, including moral obligations towards affected employees and the local community as well as business strategy purposes and mitigating negative reputation in the public eye. Some studies indicated the importance of the interaction between companies and institutional settings (i.e., legislations, norms and values, and actors in the companies' environment) in the understanding of closedown and downsizing processes. The notion of power relations, visualized by some of the included articles in the review, seems to be a useful analytical tool for further understanding the CSR during restructuring processes.

Another but closely related issue concerns the owners and managers' right to 
decide on their own whether they should assume social responsibility and, if so, how this would be done. In the fall of 2001, against the background of plant closures and mass lay-offs by the telecom company Ericsson in Sweden and worldwide, this issue triggered the Swedish government to inquire about the legal situation in the member states of the European Union (AMS 2002). The Swedish government wondered whether it was more beneficial for international groups to close in Sweden compared to other countries and whether it was necessary to tighten the legislation in this area. In contrast to Sweden, the inquiry showed that companies in Germany, France and Spain had to develop social plans for redundant employees (ibid: 75-84). For instance, in France, the country with the most progressive rules regarding social responsibility in connection with corporate restructurings, the companies had to come to agreements with relevant authorities on steps to take to improve the situation for redundant employees. Consequently, employers were given a clear social responsibility in redundant situations, according to the inquiry. However, until now, these results have had no effect on the Swedish legislation concerning closures and downsizings. Although the question was too politically sensitive, it illustrates that the social and economic effects of business closures and downsizings could be of significant importance, such that the governments would like to intervene in the stakeholder relations and change the regulative definition of corporate social responsibility. In fact, the underlying question relates to economic democracy and the effect of more equal stakeholders in the process of assuming social responsibility in connection with business closures and mass lay-offs.

The second knowledge gap that we identified concerns the outcomes of assuming social responsibility in relation to business closures and downsizings. The present review demonstrates that the current body of knowledge on CSR in connection with business closures and downsizing suffers from a serious lack of social and economic research. What are the social and economic effects of the assumed responsibility, for instance, a year or two after the closure, on the company, the employees and the local community? None of the 24 articles reviewed address this important issue. Concerning this knowledge gap, the following questions could be seen as examples of research questions to be posed: What is the importance of CSR for the redundant employees in their transition to new employment in the horizontal and vertical labour market structure? How did the socially responsible company in question collaborate with companies and transition organisations, such as the Public Employment Service, local authority organisations and schools, to secure a socially responsible result in the long run? The answers could help stakeholders prepare to better manage any future closedowns and redundancies, even if they are conducted in times of economic 
downturns.

The third knowledge gap concerns methodology. Most of the reviewed articles used a case study approach with single or only a couple of domestic cases to fulfil their aims, and they were often conducted in Sweden and the US. Comparative studies based on larger and more up-to-date domestic and international samples comprising of several continents contribute to the existing knowledge on, for instance, the interaction between stakeholders and different institutional settings. Additionally, it would be important to include both larger and smaller companies, since most of the reviewed studies focused on larger companies. Larger comparative studies would be inspired by methodological discussions on the best cases to choose and contribute to the relatively sparse debate on theory concerning the relation of CSR with business closures and downsizing. The scope for several theoretical perspectives addressing CSR in connection with closures and downsizing seems to be large.

\section{Limitations of the Review}

The literature on the CSR and downsizing or plant closure can be rather hard to grasp, which means that we may not have covered all relevant studies. Some interesting studies have, for instance, addressed "proactive HR engagement," "success factors" or "better practices" in managing downsizing or closure processes without explicitly focusing on the CSR, or social responsibility terminology (e.g., Appelbaum, Everard, \& Hung, 1999; Cascio \& Wynn, 2004; Feldman \& Leana, 1994; Marks \& Vansteenkieste, 2008). In addition, some interesting case descriptions could be illustrated as examples in book chapters and sections or other type of work, which we may not have been identified through the searches in the included databases. Nonetheless, it seems reasonable to assume that we have covered most studies included in the databases we searched that explicitly focused on CSR in connection with downsizing and business closures.

\section{REFERENCES}

Aguinis, H., \& Glavas, A. (2012). What We Know and Don't Know About Corporate Social Responsibility: A Review and Research Agenda. Journal of Management, 38(4), 932-968. http://dx.doi.org/10.1177/0149206311436079

Ahlstrand, R. (2010). Social responsibility in connection with business closures: A study of the close-down of Ericsson Telecom facilities in Norrköping and Linköping. Economic and Industrial Democracy, 31(4), 537-555. http://dx.doi.org/10.1177/0143831x10365926 
Akyildiz, F. (2006). The Failure of Multinational Companies in Developing Countries in Sharing Environmental Responsibilities: The Case of Turkey. Social Responsibility Journal, 2(2), 142-150. http://dx.doi.org/10.1108/eb059253

AMS (National Labour Market Board) (2002). Kartläggning av det europeiska rättsläget vad gäller arbetsgivarens ansvar vid företagsnedläggningar [A survey of the legal situation in Europe concerning the employer's responsibility when closing down an enterprise]. Stockholm: AMS.

Angelöw, B. (1988). Att berövas sitt arbete [To be deprived of your job], Rävlanda/Stockholm: Fri Press/Symposion Bokförlag.

Appelbaum, S.H., Everard, A., \& Hung, L.T.S. (1999). Strategic downsizing: critical success factors. Management Decision, 37(7), 535-552. http://dx.doi.org/10.1108/00251749910285674

Armstrong, K., Bailey, D., de Ruyter, A, Mahdon, M., \& Thomas, H. (2008). Auto plant closures, policy responses and labour market outcomes: a comparison of MG in the UK and Mitsubishi in Australia. Policy Studies, 29(3), 343-355. http://dx.doi.org/10.1080/01442870802160051

Avi-Yonah, R.S. (2005). The Cyclical Transformations of the Corporate Form: A Historical Perspective on Corporate Social Responsibility. Delaware Journal of Corporate Law 30(3), 767-818.

Bergström, O., \& Diedrich, A. (2011). Exercising Social Responsibility in Downsizing: Enrolling and Mobilizing Actors at a Swedish High-Tech Company. Organization Studies, 32(7), 897-919. http://dx.doi.org/10.1177/0170840611407019

Bracker J.S., \& Kinicki, A.J. (1988). Strategic Management, Plant Closings, and Social Responsibility: An Integrative Process Model. Employee Responsibilities and Rights Journal, 1(3), 201-213. http://dx.doi.org/10.1007/bf01384981

Brejning, J. (2012). Corporate social responsibility and the welfare state: the historical and contemporary role of CSR in the mixed economy of welfare. Burlington, VT: Ashgate.

Browne, A.L., Stehlik, D., \& Buckley, A. (2011). Social licences to operate: for better not for worse; for richer not for poorer? The impacts of unplanned mining closure for 'fence line' residential communities. Local Environment, 16(7), 707-725. http://dx.doi.org/10.1080/13549839.2011.592183

Browning, M., \& Heinesen, E. (2012). Effect of job loss due to plant closure on mortality and hospitalization. Journal of Health Economics, 31(4), 599-616. http://dx.doi.org/10.1016/j.jhealeco.2012.03.001 
Burchell, B. (ed.). (2008). The Corporate Social Responsible Reader. Routledge, Abington, Oxon.

Carroll, A.B. (1979). A Three Dimensional Conceptual Model of Corporate Performance. Academy of Management Review, 4(4), 497-505. http://dx.doi.org/10.2307/257850

Carroll, A.B. (1984). When business closes down: Social responsibilities and management actions. California Management Review, 26(2), 125-140. http://dx.doi.org/10.2307/41165072

Carroll, A.B. (1991). The pyramid of corporate social responsibility: Towards the moral management of organizational stakeholders. Business Horizons, 34(4), 3948. http://dx.doi.org/10.1016/0007-6813(91)90005-g

Carroll, A.B. (1999). Corporate social responsibility: Evolution of a definitional construct. Business and Society. 38(3), 268-296. http://dx.doi.org/10.1177/000765039903800303

Cascio, W.F., \& Wynn, P. (2004). Managing a downsizing process. Human Resource Management, 43(4), 425-436._http://dx.doi.org/10.1002/hrm.20034

Crane, A. \& Matten, D. (eds.) (2007a). Corporate social responsibility. Vol. 1, Theories and concepts of corporate social responsibility. London: SAGE.

Crane, A. \& Matten, D. (eds.) (2007b). Corporate social responsibility. Vol. 2, Managing and implementing corporate social responsibility. London: SAGE.

Crane, A., \& Matten, D. (eds.) (2007c). Corporate social responsibility. Vol. 3, Corporate social responsibility in global context. London: SAGE.

Crane, A., McWilliams, A., Matten, D., Moon, J., \& Siegel, D.S. (2008). The Oxford Handbook of Corporate Social Responsibility. Oxford University Press, Oxford.

Crowther, D., \& Rayman-Bacchus, L. (2004). Introduction: Perspectives on corporate social responsibility. In Crowther, D. and Rayman-Bacchus, L. (eds.) Perspectives on Corporate Social Responsibility, (pp. 1-17). Aldershot: Ashgate.

Dahlsrud, A. (2006). How Corporate Social Responsibility is Defined: an Analysis of 37 Definitions. Corporate Social Responsibility and Environmental Management, 15(1), 1-13.

Datta, D. K., Guthrie, J. P., Basuil, D., \& Pandey, A. (2010). Causes and Effects of Employee Downsizing: A Review and Synthesis. Journal of Management, 36(1), 281-348.

Dobbers, P., \& Halme, M. (2009). Corporate Social Responsibility and Developing Countries. Corporate Social Responsibility and Environmental Management, 16(5),37-249. http://dx.doi.org/10.1002/csr.212 
Dobbers, P. (ed.) (2010). Corporate Social Responsibility. Challenges and Practises. Stockholm: Santérus Academic Press Sweden.

Droppert, H., \& Bennett, S. (2015). Corporate social responsibility in global health: an exploratory study of multinational pharmaceutical firms. Globalization and Health, 11(15), 1-8. https://doi.org/10.1186/s12992-015-0100-5

Durst, S., \& Edvardsson, I. R. (2012). Knowledge management in SMEs: a literature review. Journal of Knowledge Management, 16(6), 879-903. http://dx.doi.org/10.1108/13673271211276173

Edvardsson, I. R., \& Durst, S. (2014). Outsourcing of knowledge processes: a literature review. Journal of Knowledge Management, 18(4), 795-811. http://dx.doi.org/10.1108/jkm-01-2014-0033

Eliason, M., \& Storrie, D. (2006). Latent or Lasting Scars: Swedish evidence on the long-term effect of job displacement. Journal of Labor Economics, 24(4), 831-56. http://dx.doi.org/10.1086/506487

Eliason, M., \& Storrie, D. (2009). Does Job Loss Shorten Life? Journal of Human Resource Management, 44(2), 277-302. http://dx.doi.org/10.1353/jhr.2009.0020

Feldman, D.C. \& Leana, C.R. (1994). Better practices in managing layoffs. Human Research Management, 33(2) 239-260.

Filatotchev, I., \& Stahl, G. K. (2015). Towards transnational CSR. Corporate social responsibility approaches and governance solutions for multinational corporations. $\begin{array}{lll}\text { Organizational Dynamics, } & \text { 44(2), }\end{array}$ http://dx.doi.org/10.1016/j.orgdyn.2015.02.006

Gonäs, L., Haraldsson, K., Hellbom, L., Levinson, K., Mossfeldt, P., \& Svanljung, N. (1979). Emmabodarapporten. En studie i strukturomvandling [The Emmaboda report. A study of structural change]. Stockholm: Arbetslivscentrum.

Gonäs, L. (1989). En fråga om kön. Kvinnor och män i strukturomvandlingens spår [A matter of gender. Women and men in the tracks of structural change]. Stockholm: Arbetslivscentrum.

Gonäs, L., \& Westin, H. (1993). Industrial Restructuring and Gendered Labour Market Processes. Economic and Industrial Democracy, 14(3), 423-457. http://dx.doi.org/10.1177/0143831x93143008

Habish, A., Joker, J., Wegner, M., \& Schmidpeter, R. (2005). Corporate Social Responsibility Across Europe. Berlin: Springer.

Hansson, M., \& Wigblad, R. (2006). Pyrrhic victories - anticipating the closedown effect. The International Journal of Human Resource Management, 17(5), 938958. http://dx.doi.org.proxy.mah.se/10.1080/09585190600641255 
Hironimus-Wendt, R.J. (2008). The Human Costs of Worker Displacement. Humanity \& Society, 32(1), 71-93. http://dx.doi.org/10.1177/016059760803200105

Hopkins, W. E., \& Hopkins, S. A. (1999). The ethics of downsizing: Perception of rights and responsibilities. Journal of Business Ethics, 18(2), 145-156.

Ite, U.E. (2004). Multinationals and corporate social responsibility in developing countries: a case study of Nigeria. Corporate Social - Responsibility and Environmental Management, 11(1), 1-11. http://dx.doi.org/10.1002/csr.49

Jamali, D., Lund-Thomsen, P., \& Jeppesen, S. (2017). SMEs and CSR in Developing $\begin{array}{llll}\text { Countries. Business } \quad \& \quad \text { Society, } & \text { 56(1), }\end{array}$ https://doi.org/10.1177/0007650315571258

Jamali, D., Lund-Thomsen, P., \& Khara, N. (2017). CSR Institutionalized Myths in Developing Countries: An Imminent Threat of Selective Decoupling. Business \& Society, 56(3), 454-486, https://doi.org/10.1177/0007650315584303

Jones, B., \& Nisbet, P (2011). Shareholder value versus stakeholder values: CSR and financialization in global food firms. Socio-Economic Review, 9(2), 287-314. http://dx.doi.org/10.1093/ser/mwq033

Karake, Z.A. (1998). An examination of the impact of organizational downsizing and discrimination activities on corporate social responsibility as measured by a company's reputation index. Management Decision, 36(3), 206-216.

Karlsson, T. (2013). The Dynamics of Downsizing: The Swedish Tobacco Monopoly in the 1920s. Enterprise and Society, 14(4), 829-853. http://dx.doi.org/10.1093/es/kht074

Kothen, C., McKinley, W., \& Scherer, A.G. (1999). Alternatives To Organizational Downsizing: A German Case Study.M@n@gement,2(3),263-286

Littlewood, D. (2014).'Cursed' Communities? Corporate Social Responsibility (CSR), Company Towns and the Mining Industry in Namibia. Journal of Business Ethics, 120(1), 39-63. http://dx.doi.org/10.1007/s10551-013-1649-7

Marano, V., \& Kostova, T. (2016). Unpacking the Institutional Complexity in Adoption of CSR Practices in Multinational Enterprises. Journal of Management Studies, 53(1), 28-54.

Marks, M. L., \& Vansteenkieste, R. (2008). Preparing for organizational death: Proactive HR engagement in an organizational transition. Human Resource Management, 47(4), 809-827. https://doi.org/10.1002/hrm.20246

Martinez-Conesa, I., Soto-Acosta, P., \& Palacios-Manzano, M. (2017). Corporate social responsibility and its effect on innovation and firm performance: An empirical research in SMEs. Journal of Cleaner Production, 142(4), 2374-2383. http://dx.doi.org/10.1016/j.jclepro.2016.11.038 
Matten, D., \& Moon, J. (2008). "Implicity" and "Explicity" CSR: A Conceptual Framwork for a Comparative Understanding of Corporate Social Responsibility. The Academy of Management Review, 33(2), 404-424. http://dx.doi.org/10.5465/amr.2008.31193458

Mayes, R., Pini, B., \& McDonald, O. (2012). Corporate social responsibility and the parameters of dialogue with vulnerable others. Organization, 20(6), 840-859. http://dx.doi.org/10.1177/1350508412455083

McMahon, T.F. (1999). From social irresponsibility to social responsiveness: The Chysler/Kenosha plant closing. Journal of Business Ethics, 20(2), 101-111.

McWilliams, A., \& Siegel, D. (2001). Corporate social responsibility: A theory of the firm perspective. Academy of Management Review, 26(1), 117-127. http://dx.doi.org/10.2307/259398

Millspaugh, P. E. (1990). Plant closing ethics root in American law. Journal of Business Ethics, 9(8), 665-670. http://dx.doi.org/10.1007/bf00383393

Moir, L. (2001). What do we mean by corporate social responsibility? Corporate Governance, 1(2), 16-22.

Ramsey, H. (2014). Practicing social responsibility by helping severed employees grieve a job loss. The Psychologist-Manager Journal, 17(2), 79-86. http://dx.doi.org/10.1037/mgr0000013

Rydell, A., \& Wigblad, R. (2012). The Quest for CSR in Closedowns. Nordic Journal of Working Life Studies, 2(3), 163-180. http://dx.doi.org/10.19154/njwls.v2i3.2368

Rydell, A., \& Wigblad, R. (2011). Company-level flexicurity during the restructuring process: a model. Transfer: European Review of Labour and Research, 17(4), 547-562. http://dx.doi.org/10.1177/1024258911419781

Schwartz, M.S., \& Carroll, A. B. (2003). Corporate Social Responsibility: A ThreeDomain Approach. Business Ethics Quarterly, 13(4), 503-530. http://dx.doi.org/10.5840/beq200313435

Stoian, C. \& Gilman, M. (2017). Corporate Social Responsibility That "Pays": A Strategic Approach to CSR for SMEs. Journal of Small Business Management, 55(1), 5-31. https://doi.org/10.1111/jsbm.12224

Stjernberg, T., \& Tillberg, U. (1998). When Structure and Meaning Break Down Taking Responsibility in Downsizing. European Journal of Work and $\begin{array}{lll}\text { Organizational Psychology, } & \text { 7(3), }\end{array}$ http://dx.doi.org/10.1080/135943298398754 
Tang, T. L-P., \& Crofford, A. B. (1999). The Anticipation of Plant Closing: Employee Reactions. Journal of Social Psychology, 139(1), 44-48. http://dx.doi.org/10.1080/00224549909598360

Tesfom, G., \& Birch, N.J. (2008). Do offshore outsourcing firms in the USA use their investments on corporate social responsibility to alleviate negative attitudes toward offshore outsourcing? Social Responsibility Journal, 4(4), 428-438. http://dx.doi.org/10.1108/17471110810909849

Van Buren, H.J. III. (2000). The bindingness of social and psychological contracts: Toward a theory of social responsibility in downsizing. Journal of Business Ethics, 25(3), 205-219.

Visser, W., Matten, D., Pohl, M., Tolhurst, N. (2008). The A to Z of Corporate Social Responsibility: A Complete Reference Guide to Concepts, Codes and Organisations. Chichester: John Wiley \& Sons.

Wigblad, R. (1995). Community turnarounds in declining company towns: A restructuring model. The Journal of Socio-Economic, 24(3), 463-475. http://dx.doi.org/10.1016/1053-5357(95)90018-7

Williams, C.A. \& Aguilera, R.V. (2008) Corporate social responsibility in a comparative perspective. In: Crane, A. McWilliams, A. Matten, D. Moon, J. \& Siegel, D.S. (eds.) The Oxford handbook of corporate social responsibility. (pp. 452-552). New York: Oxford University Press.

Zyglipoulos, S.C. (2004). The impact of downsizing on the corporate reputation for social performance. Journal of Public Affairs, 4(1), 11-25. http://dx.doi.org/10.1002/pa.168 
